\title{
VALUE OF IMMUNOHISTOCHEMICAL DETERMINATION OF SYNDECAN-1 IN BREAST CANCER
}

\author{
IVANA MIŠE \\ Cytology Unit, Department for Pathology, Farwaniya Hospital, Kuwait
}

\begin{abstract}
Summary
Syndecan-1 (Sdc1) is a transmembrane heparan-sulfate proteoglycan, an extracellular matrix receptor and a cell-matrix adhesion organiser, included in adhesion of all cell's contact surfaces. It integrates different cellular signals and signals between growth factors, and modulates cell proliferation, carcinogenesis, migration and angiogenesis. Cellular motion and invasion first require loss of the Sdc1. Sdc1 expression is lost shortly before the cell changes shape or location, which decrease adhesiveness but enhance cellular mobility and their invasive potential. Releasing of Sdc1 from the cell surface (shedding) enables tumor growth and metastasizing. Such change of the Sdc1 expression is of crucial value for transition of invasive breast carcinoma to metastatic phenotype, and it is a part of epithelial-to-mesenchymal transition (EMT). Molecules included in EMT are potential targets for anticancer pharmacotherapy and control of tumor metastasizing. Maybe proteolytic conversion from insoluble (membrane bound coreceptor) to soluble Sdc1 is trigger for turning of proliferative phase of breast cancer to invasive one, which can also be of potential diagnostic-therapeutic benefit. Stromal Sdc1 expression means not merely the simple fixation of the released Sdc1 from the epithelial cells to the stromal, but also autochthonous Sdc1 synthesis in reactive stromal fibroblasts. By interacting with heparin-binding growth factors, Sdc1 accumulates in the stro$\mathrm{ma}$ and can contribute to proliferation of invasive tumor stroma and neoangiogenesis. In more than $70 \%$ of breast carcinomas Sdc1 is induced in stromal fibroblasts, with the significant difference in its expression between stroma of malignant and non-malignant breast tissue. Although part of breast cancers loses Sdc1, in most of them it is expressed or over-expressed, and its expression is associated with a poorer response of this cancer to chemotherapy. Studies about prognostic significance of Sdc1 in breast cancer have shown unequal results, which refers to the need for new researches on this subject.
\end{abstract}

KEYWORDS: breast, cancer, syndecan-1, immunohistochemistry, expression

\section{INTRODUCTION}

Syndecan-1 (Sdc1) is a transmembrane heparan sulfate proteoglycan (HSPG), an extracellular matrix $(E C M)$ receptor and cell-matrix adhesion organiser, active participant in all important cellular and tissue processes such as inflammation, repair, immune response, metabolism, apoptosis, carcinogenesis and metastasizing, insurer of the integration of different cellular signals and signals between growth factors, and modulator of the cell proliferation, migration, invasion and angiogene-

Corresponding author: Ivana Miše, Cytology Unit, Department for Pathology, Farwaniya Hospital, 7WC4+C3 Sabah Al Nasser, Kuwait.e-mail: ivana.mise@gmail.com sis (1-6). Also known as CD138, it is expressed in normal and malignant tissue; predominantly on/ in epithelial cells, but it can be found in mesenchymal cells during their development and in the stroma of different malignant tumors, at various stages of activation and differentiation of normal lymphoid cells (i.e. in centrocytes, not centroblasts), in normal mature plasma cells and atypical plasma cells in multiple myeloma (MM) (7). It is mostly expressed on the surfaces of adherent epithelial cells; e.g. during differentiation, stratification and maturation of keratinocytes, when intercellular adhesion is enhanced, the quantity of Sdc1 on cells surfaces is increased in comparison to non-stratified cells, meaning it is included in 
the adhesion process on all contact cell surfaces $(8,9)$. Most probable Sdc1 mediates the adhesion of mesenchymal cells too; after the disaggregation of mesenchymal cells in vitro, it was found to be intensely expressed on cells that re-aggregated (10). Interestingly, the Sdc1 expression, similar to the expression of other adhesion molecules, such as cadherin, is lost shortly before the cell changes shape or location $(11,12)$. Similar processes have been shown during malignant transformation and tumor progression, so probable the cellular motion and invasion first require loss of Sdc1 and decrease in cellular adhesion capacity.

The prognostic value of Sdc1 was investigated in various carcinomas - including breast, colorectal, gastric, pancreatic and liver, prostate and bladder, lung, endometrium and ovary, head and neck, MM. Sdc1 loss is mainly associated with aggressive tumor phenotype and poor prognosis of the disease. Similarly, the reduction of Sdc1 expression in carcinomas is mostly associated with histological (de)differentiation and/or tumor grade. In poorly differentiated tumors, there is often a loss of expression, although different histological types as well as carcinomas of different body sites show differences in Sdc1 expression and its meaning; for example, in planocellular carcinoma of the head and neck the Sdc1 expression means a better prognosis, while - according to certain studies - its high level in breast cancer correlates with a more aggressive phenotype and poor prognosis. Inconsistent and contradictory results indicate the involvement of other factors in the molecular oncogenesis, which are necessary for understanding Sdc1 expression.

\section{The role of Sdc1, ECM and stromal fibroblasts in breast cancer initiation and progression}

The significance of the Sdc1 in a breast carcinoma has been more frequently the subject of interest - sometimes from an exclusive narrow molecular aspect (13) and sometimes from the clinicalprognostic aspects (14). In tumor progression, Sdc1 makes an impact on several levels, and it can act as a supressor and as a tumor-growth promoter, depending on the type of tumor and localization of proteoglycan - on the cell surface or released in the microenvironment or in both locations.

In a healthy breast and physiological conditions, the gene expressions for $\mathrm{Sdc} 1$, syndecan-4
(Sdc4) and decorin is significantly lower in the luteal phase of the menstrual cycle compared to the follicular phase, which is a possible result of ovarian hormones activity and is the basis for further studies, for example in women on hormone therapy or women with breast cancer (15). Increased progesterone in the luteal phase of the cycle interacts with growth factors increasing their synergistic and inhibitory effects, thus affecting the ECM structure (16). Healthy breast stroma in comparison to the tumour stroma in postmenopausal women shows significantly lower Sdc1 - its value in malignant stroma being $>10 \mathrm{x}$ higher, with almost extreme Sdc1 redistribution from the epithelium to the stroma (17). By comparing the mammographically detected healthy breast tissue density with the Sdc1 expression in postmenopausal women with breast cancer, a strong correlation was found between the epithelial estrogen receptor-alpha (ER-alpha) and Sdc1 found in the stroma of mammographically detected high density tissue, not recorded in low density tissue (18). The results of these two studies suggest that a significant increase of Sdc1 in malignant stroma and the redistribution of Sdc1 in the direction of epitheli$\mathrm{um} \rightarrow$ stroma are in connection with the biological baseline of the disease, which is also reflected in the breast tissue density $(17,18)$. Glandular (epithelial) Sd1 expression is lower in malignant breast tumors than in benign or normal breast tissue in premenopausal women, with the opposite findings in the stroma, as well with the change of Sdc1 localization from epithelial to stromal cells in malignant tissue (19).

The loss of Sdc1 expression reduces cell adhesion, increases the invasive potential and deregulates the growth of epithelial breast cells. Stanley et al. have demonstrated a significantly lower Sdc1 expression on malignant cells of the invasive ductal carcinomas (IDCs) in comparison to Sdc1 expression in healthy tissue and epithelial-stromal tumors (20). A significant difference was found between Sdc1 expression in malignant and nonmalignant stromal breast tissue. It was strongly expressed in the stroma and on the border of epithelium-stroma in IDCs, but absent in the stroma of healthy tissue and epithelial-stromal tumors. Breast stroma is important in response modulation of epithelial cells to sex hormones, and ECM proteoglycans have an important role in signalling between components of different tissues. By 
interacting with heparin-binding growth factors such as fibroblast growth factor-2 (FGF-2), Sdc1 accumulates in the stroma and can contribute to angiogenesis and proliferation of invasive tumor stroma. Such a change in Sdc1 expression is of crucial importance in IDC transition to a metastatic phenotype. The induction of Sdc1 in the stroma is connected to expression loss in malignant epithelial cells (20).

In more than $70 \%$ of breast carcinomas Sdc1 is induced in stromal fibroblasts. Maeda et al. have shown that Sdc1 from stromal fibroblasts stimulates the proliferation of malignant epithelial cells in mice, with significant acceleration of tumor growth and further growth increase (for 88\%) in case of severe expression (21). Increased expression of stromal Sdc1 was also connected to significant density increase of smaller (to $36 \%$ ) and larger (up to $15 \%$ ) blood vessels. A similar result was found in 207 specimens of human breast cancer (21). Sdc1 is necessary for the growth of reactive stroma. By inoculating the culture of a highly invasive breast cancer cell line into the embryonic fibroblast co-culture in mice, Maeda et al. have induced Sdc1 expression, which was absent following the inoculation of less invasive malignant and normal cell lines. Stroma growth has been completely stopped by inserting a gene for mutated Sdc1 that lacks a heparan sulfate locus. Sdc1 induction into stromal fibroblasts stimulates multiplication of malignant epithelium, suggesting interaction of malignant cells and surrounding stroma dependent on the activity of glycosylated Sdc1 (22). Stromal Sdc1 expression means the occurrence of strong immunoreactivity in reactive stromal cells of invasive tumors and their autochthonous Sdc1 synthesis, not merely the simple fixation of the released Sdc1 from the epithelial cells to the stromal (23). Spindle cells of connective tissue with myofibroblastic differentiation that may contribute to tumor cell dedifferentiation and metastases development in breast, lung, colon and bladder cancer, show high Sdc1 expression (23).

Although part of breast cancer loses Sdc1, in most carcinoma it is expressed or over-expressed. Cells of poorly differentiated tumors contain intracellular Sdc1; in vitro they internalise the intact Sdc1 from the surface where it gradually accumulates into intracellular lysosomes where it breaks down, while the cells of well differentiated tumors retain most of Sdc1 on the surface, but also internalise it to lysosomes (24). The Sdc1 ectodomain regulates the matrix-dependent signalling. Increases in the level of surface Sdc1 in the culture of breast cancer cells, changes the signalling dependent on the matrix, which can result in weaker cell cohesion and invasion in the early tumorigenesis (25). It is not completely clear how the released Sdc1 accelerates tumor growth. Maybe Sdc1 ectodomain affects the extracellular proteolysis - necessary for tumor invasion and metastasizing, similar to its activity in acute wound fluids (26). Sdc1 over-expression promotes metastasizing of breast cancer cells to the brain via cytokines, which can modulate bloodbrain barrier in vitro (27).

By releasing Sdc1 from the cell surface growth, angiogenesis and tumor metastasizing are made possible. Heparanase enzyme on tumor cells is a strong promoter of tumor progression and metastasizing. It regulates the level and location of Sdc1 in the tumor microenvironment by increasing its synthesis and release (28). Such regulation of Sdc1 by heparanase has been demonstrated in MM and breast cancer cell lines, where both markers act synergistically in the stimulation of an aggressive tumor phenotype. By removing heparan sulfate from the cell surface by a bacterial heparitinase, dramatically accelerates the release of Sdc1, which means that the effects of heparanase on Sdc1 expression in tumor cells are at least, in part, mediated by the reduction in the size of Sdc1 heparan sulfate chains (28).

The two forms of Sdc1, the membrane bound coreceptor and the soluble effector form, are capable of binding the same ligands, but with different roles in different stages of breast cancer and its progression (29). It is possible that the proteolytic conversion of insoluble to soluble form is a trigger to turn the proliferative stage of breast cancer in the invasive, which could be useful in the diagnosis and potential glycosaminoglycan treatment of this cancer (29). Both - the composition and changes in the proteoglycan structure during malignant transformation, affect the adhesive abilities and mitotic activity of tumor cells. Changes in the expression intensities of Sdc1, decorins and lumicans in tumor breast tissue can induce the mitotic activity of tumor cells (30). A strong negative correlation of Sdc1 with ECM components, especially collagen IV and tenascin, confirms its role in the remodelling of breast cancer tissue and its significance in tumor progression (31). As well, Sdc1 

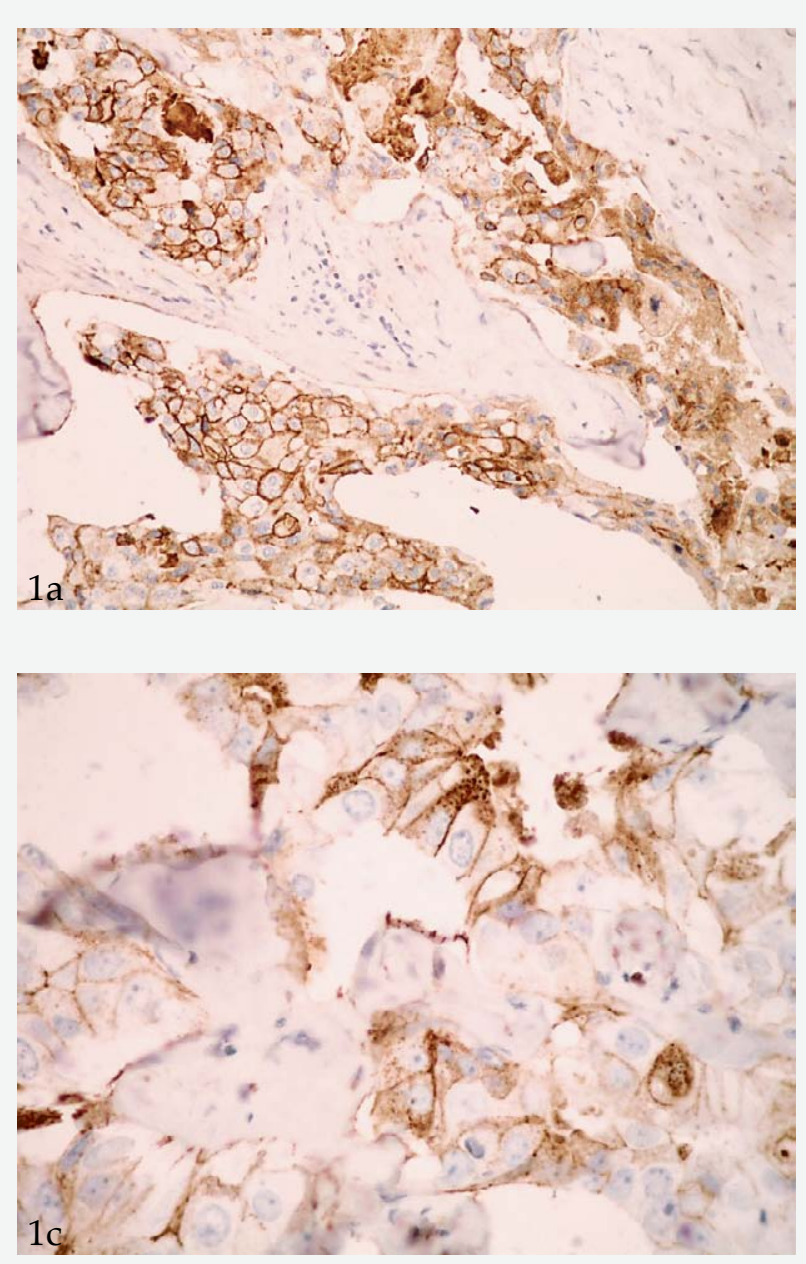

modulates assembly of 3D fibrillar ECM - directly by interacting with fibronectin via its heparan sulfate chains and by activating integrin $\alpha \mathrm{v} \beta 3$ via its ectodomain; such amazing rearrangement of ECM in terms of alignment, creates a kind of stromal highways for spreading of malignant epithelial cells that certainly accelerate their progression and metastasizing, but also may lead to new stroma-targeted therapy by altering an invasion-permissive to invasion-restrictive tumor microenvironment in breast cancer (32).

\section{Sdc1 and epithelial-to-mesenchymal-transition in breast cancer}

Tumor growth is evidence of changes to its structure through specific adjustment of tissue called epithelial-to-mesenchymal transition (EMT), but it also occurs in physiological processes of

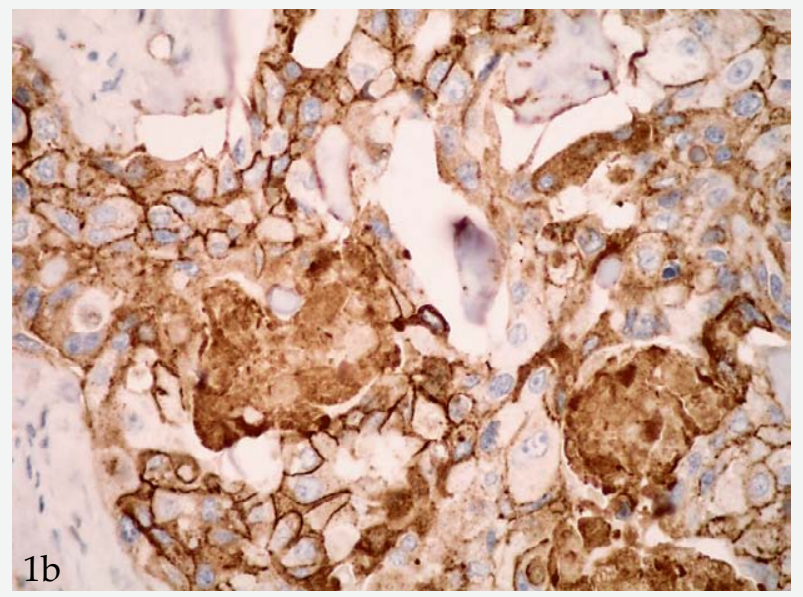

Figure 1a. Strong epithelial (both membranous and cytoplasmic) and absence of stromal Sdc1 expression, IDC (IHC, x200)

Figure 1b. Strong epithelial (both membranous and cytoplasmic) Sdc1 expression, with the accumulation of Sdc1 in the intraluminal necrotic tumor mass, IDC (IHC, $x 400$ )

Figure 1c. Moderate to strong epithelial Sdc1 expression - membranous and focally strong granular cytoplasmic positivity, IDC (IHC, x400)

growth and development, when epithelial cells exhibit reduced adhesion, increased mobility and acquire mesenchymal features similar to fibroblasts $(33,34)$. The disruption of intercellular connections and an increase in mobility of cells being released from the original epithelium are therefore essential. Such a phenotype similar to mesenchyme facilitates migration, but also invasion, dissemination and metastasis of malignant cells. EMT has a critical role in malignant transformation and progression by providing the initial tumor with invasive and metastatic traits. Although the molecular mechanism of EMT is not fully known, several signalling molecules that potentially induce it have been identified (growth factors, tyrosine kinase receptors, $\beta$-catenin, integrins), as well as signalling pathways (e.g. phosphatidylinositol 3' kinase/Akt axis) leading to 

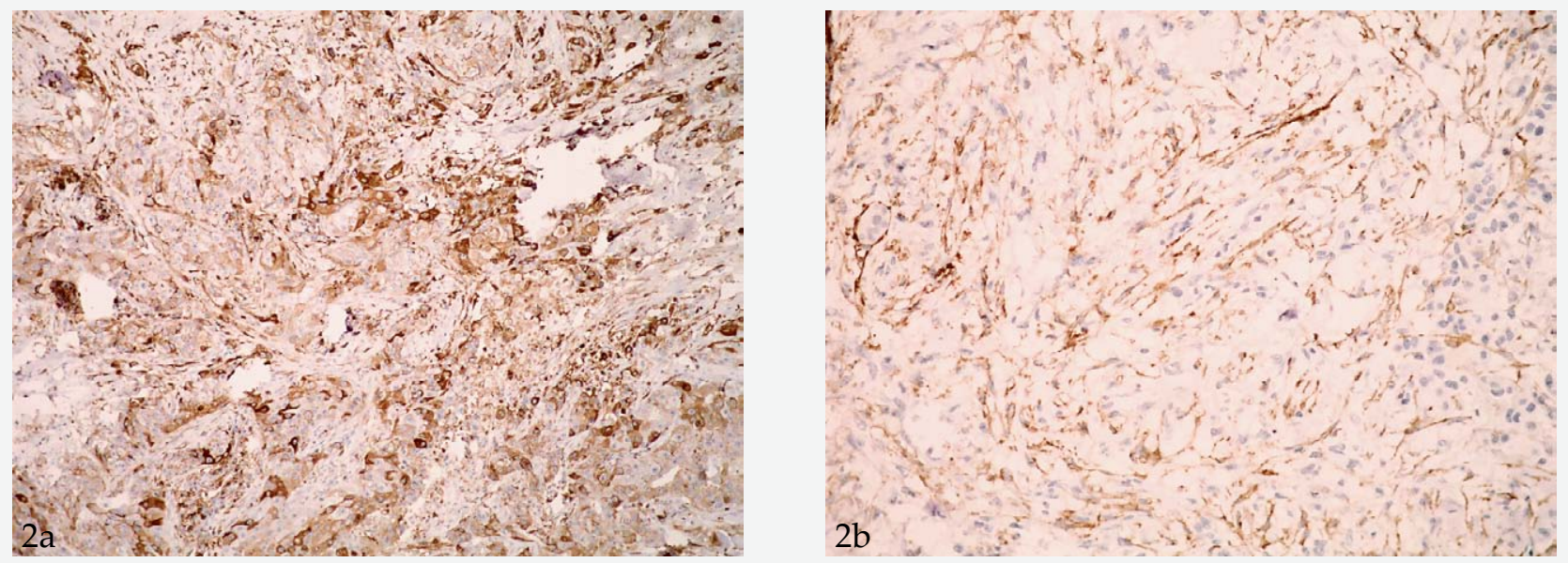

Figure 2a. Moderate to focally strong epithelial, and focally weak to moderate stromal Sdc1 expression, IDC (IHC, x100)

Figure 2b. Moderate stromal and absence of epithelial (loss) Sdc1 expression, IDC (IHC, x200)
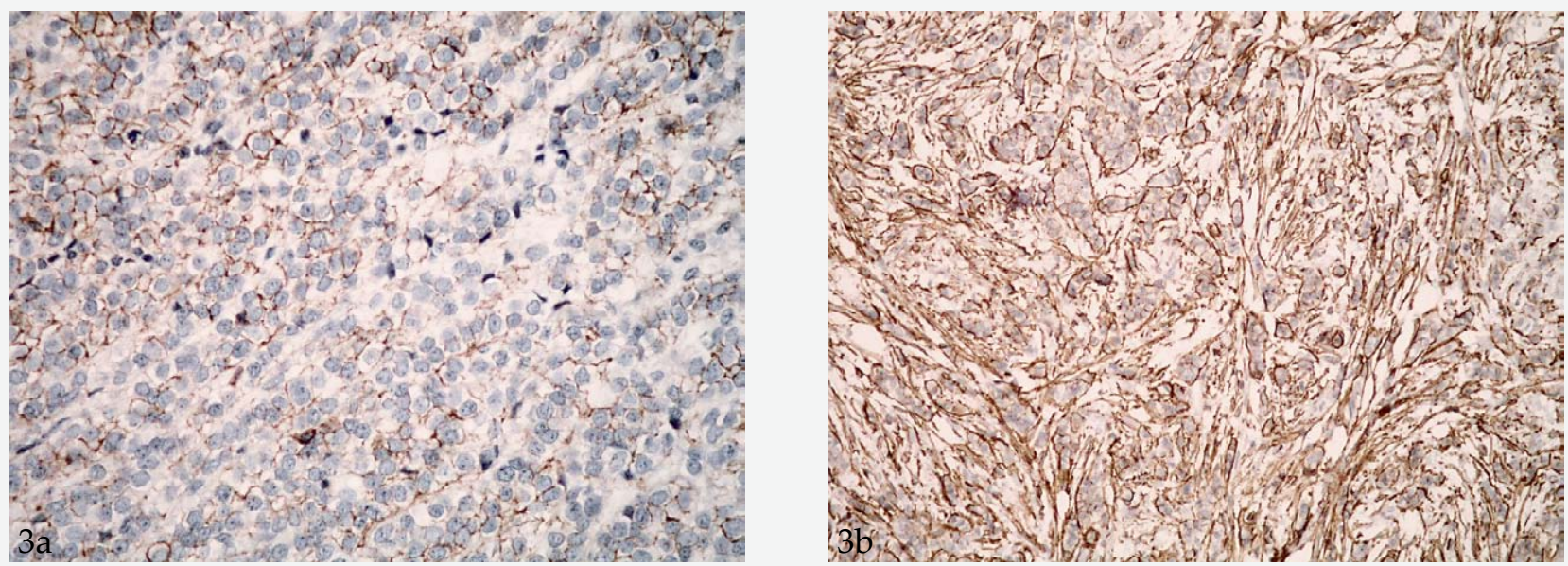

Figure 3a. Weak to moderate epithelial Sdc1 expression, ILC (IHC, x400)

Figure 3b. Strong stromal and absence of epithelial (loss) Sdc1 expression, ILC (IHC, x200)

reduction or loss of the E-cadherin adhesion molecule $(33,34)$. Gen E-cadherin is inactivated in diffuse carcinomas such as lobular breast carcinoma and diffuse gastric cancer, where malignant cells within the entire tumor mass lose more of their epithelial properties and become highly invasive (33). However, a reduction of E-cadherin is also seen in solid non-diffuse tumors on epithelial-stromal border where malignant cells invade individually. This would mean that the loss of Ecadherin and EMT can be reversible processes, probably regulated by the tumor microenvironment. Malignant epithelial cells that passed the transition to the mesenchymal phenotype during the invasion, could again obtain E-cadherin expression and epithelial (cohesive) features in secondary focuses (33). Thanakit et al. also point to the possibility of E-cadherin re-expression due to it being highly expressed in metastatic axillary nodes in breast cancer (35). During the transition from epithelial to less differentiated mesenchyimal phenotype or during EMT, the malignant cells lose Sdc1 as well. The change in Sdc1 expression from malignant epithelial to reactive stromal cells was found during progression of various carcinomas including breast cancer (36-38). 
The critical feature of EMT is reduced expression of both markers - E-cadherin and Sdc1 on tumor cells $(36,37)$. E-cadherin gene, otherwise responsible for epithelial cell cohesion, is absent in $80-100 \%$ of invasive lobular carcinomas (ILCs), and its inactivation is an early molecular event in its oncogenesis (39). In our research about differences in Sdc1 expression between IDCs and ILCs, we suggested, among other things, a possible stronger association between Sdc1 and E-cadherin in lobular than in ductal cancers, with the assumption that somewhat weaker stromal Sdc1 expression in lobular tumors is probably connected with a greater E-cadherin loss, i.e. that tumor cells of lobular carcinomas lose more Sdc1 during EMT than ductal malignant cells undergoing EMT (38). It may be supported by the fact that in our study the epithelium of both primary carcinomas expressed Sdc1 in exactly the same way - in $90 \%$ of cases. Therefore, it unevenly loses Sdc1 during EMT (which is probably linked with a loss of Ecadherin as described), or the induction of Sdc1 is possible weaker in the stroma of lobular cancers. As previously mentioned, Sdc1 is partly synthesized in the stroma itself, i.e. in the stromal fibroblasts, that raises the hypothesis of its possible lower synthesis in the stromal fibroblasts of ILCs. This can be supported by our results of Sdc1 expression distribution in primary ILCs, according to which the stroma of ILC often, or - in as many as $40 \%$, did not show even a weak Sdc1 expression (38) (Figures 1a, $1 \mathrm{~b}$ and $1 \mathrm{c} ; 2 \mathrm{a}$ and $2 \mathrm{~b}$; $3 \mathrm{a}$ and $3 \mathrm{~b}$ ). All molecules included in EMT are potential targets for pharmacological treatment and open new possibilities for tumor metastasis control (33).

\section{Some more recent morphological and clinical-prognostic studies about Sdc1 in breast cancer}

The significance of Sdc1 in breast ductal carcinoma in situ (DCIS) is not known enough. Tiemann et al. explored the Sdc1 expression in 127 DCIS cases of different nuclear grades and concluded that nuclear grade and Sdc1 tissue localization correlate significantly, that is, the tissue localization of the Sdc1 in DCISs of different grades is significantly divergent, which suggests its specific influence on DCIS biopathology and progression (40). Expression of Sdc1, E-cadherin and c-Met (a receptor for the hepatocyte growth factor) is associated with the promoters of tumor angiogenesis and lymphangiogenesis in breast DCIS (41). 72\% of DCISs show strong Sdc1 expression (significantly more often DCISs compared to the tumors with an invasive component), with a correlation between Sdc1 expression level and HER2/neu. E-cadherin expression is related to the expression of Sdc1 and c-Met. The co-expression of these markers may mean parallel activation of different signalling pathways in cell proliferation and neoangiogenesis (receptor tyrosine kinase, nuclear transcription factor), but also a new, effective treatment approach with multiple target molecules in the initial progression of breast cancer (41). Extracapsular tumor expansion outside the affected axillary lymph nodes, significantly increases the risk of local recurrences and distant metastases in breast cancer, and is associated with a greater number of metastatic nodes and larger primary tumors (35). Both - Sdc1 and E-cadherin (its re-expression?) are increasingly expressed in metastatic lymph nodes, indicating the coordinated action of both markers in tumor aggression and invasion of the axillary tissue (35).

With a key role in the development and progression of breast cancer, estrogens have multiple effects on ECM molecules. Sdc1 and Sdc4 are excessively expressed in ER negative, highly proliferative breast carcinoma (42). Baba et al. have showed a significant correlation between the expression of Sdc1, Sdc4 and glypican-1 (besides syndecans, one of the main cell surface HSPGs) with a cell proliferation marker - Ki67. Sdc1 and Sdc4 expressions - ranging from total loss to strong expression, correlated with a negative ER, grade and size of the primary tumor; Sdc1 was a predictor of clinical behaviour, but not an independent prognostic marker. A strong correlation between surface HSPGs and Ki67 confirms their role in tumor growth regulation. The expression of syndecans and a negative ER are associated with an aggressive, ER-negative type of breast cancer (42).

Leivonen et al. have evaluated the prognostic value of Sdc1 expression in 200 samples of invasive breast cancer, with a median follow-up period of 17 years (43). Epithelial Sdc1 expression appeared in $61 \%$ of tumors, while stromal Sdc1 expression showed $67 \%$ of tumors. Epithelial expression was associated with a negative ER status, and stromal expression with positive ER. 65\% of patients with tumors showing epithelial Sdc1 
expression have lived for ten years, and $82 \%$ of patients with the loss of epithelial expression. $66 \%$ of patients with positive stromal Sdc1 expression have lived for ten years, and $83 \%$ of those with negative stromal Sdc1 expression. Only $56 \%$ of patients with both expressions have lived for ten years, and $78 \%$ of patients with other combinations of epithelial-stromal Sdc1 expression. Only the axillary metastases and tumor size have shown as significant predictors of survival. The simultaneous epithelial-stromal Sdc1 expression may mean a poorer prognosis for breast cancer, and contrary to the results of other similar studies, the loss of the epithelial Sdc1 is associated with a significantly more favorable prognosis (43).

Both - epithelial and stromal Sdc1 expressions have prognostic value in various carcinomas, including breast cancer (43-45). Loussouarn et al. reevaluated the prognostic significance of Sdc1 in breast IDCs, by comparing Sdc1 expression with clinicopathological parameters and relapse-free survival (RFS) of patients (45). They found a significant correlation between loss of epithelial and stromal Sdc1 expression with high histological grade and aggressive tumors. They associated a strong epithelial Sdc1 expression with a low grade and well differentiated breast carcinomas, and a reduction of expression with poorly differentiated ones. The prognosis for the tumors with epithelial Sdc1 expression, exclusively or together with a stromal is excellent, while it is bad for those without an epithelial expression. The loss of epithelial Sdc1 expression correlated with RFS and showed prognostic value (45). Barbareschi et al. identified the increased Sdc1 expression in $42 \%$ of breast cancers, mostly in large tumors, with a high grade and high mitotic index, ER/progesterone receptor (PR) negative and HER2/neu over-expression, associated it with an aggressive phenotype and poor prognosis, while the stromal expression was not observed from the prognostic point of view (44). Malek-Hosseini et al. determined a positive correlation between the soluble Sdc1 levels (from breast cancer patients' sera) and a tumor size, which also suggest the importance of the Sdc1 different forms (cell-bound and soluble) in the progression of this carcinoma (46).

Sdc1 expression is associated with a poorer response of breast cancer to chemotherapy. Götte et al. have demonstrated the influence of Sdc1 expression and its expression level to the response to the neoadjuvant chemotherapy in locally advanced breast cancer (47). Sdc1 was expressed in $43.2 \%$ of carcinoma, more often in the ductal histological type. The response to therapy was reduced in Sdc1-positive patients, none of whom showed complete remission. None of the tumors sensitive to chemotherapy have shown a strong Sdc1 expression, while it was found in $20 \%$ of resistant tumors (47). Breast cancer stroma of preoperatively treated patients varies from those of untreated patients; Sdc1 was significantly reduced and collagen-IV elevated in the tumor stroma of preoperatively treated patients. Tenascin- $C$ was elevated in the stroma of patients with progressive disease, while smooth muscle actin did not show significant difference in expression (48).

Kind et al. analyzed separately membranous, cytoplasmic and stromal Sdc1 expression in 1535 breast cancers; loss of membranous and the presence of cytoplasmic and stromal Sdc1 expression were-to a variable degree-associated with high $\mathrm{pT}$, high grade, nodal metastases, ER/PR negative, HER2neu positive and poor overall survival (49). The best prognosis had patients with stromal Sdc1 positivity and cytoplasmic negativity, and the worst prognosis patients with opposite findings cytoplasmic positivity and stromal negativity, so they connected cytoplasmic Sdc1 expression with aggressive, and stromal with a more favourable outcome (49). Similar correlations between Sdc1 over-expression with main prognostic factors and poor overall survival in breast cancer were obtained by other authors $(50,51)$.

In our study, we determined the Sdc1 expression in malignant epithelium and stroma of 30 ILCs and 30 IDCs, and in the axillary metastases of the latter, comparing them with each other and with some clinical and histological parameters (38). Sdc1 was altogether expressed in the tumor epithelium of $90 \%$ carcinomas of both histological types, most commonly in the stroma of both types as well, but absent in the stroma of $40 \%$ ILCs. It was also expressed in the tumor epithelium of as many as $86.7 \%$ IDC metastases (strongly in 50\%), while the stroma of $46.7 \%$ metastases was negative. In primary IDCs, a negative correlation of epithelial Sdc1 and PR expression was detected, and in ILCs a positive correlation of stromal Sdc1 and histological grade. Axillary IDC metastases showed a negative correlation of Sdc1 from tumor epithelium with the patient age and ER/PR of pri- 
mary tumors, and a positive correlation of Sdc1 from metastatic stroma with number of primary tumor foci or a negative correlation with PR expression in primary tumors (38). However, the topics that associate Sdc1 expression in the primary breast cancers and its metastases are insufficient, as well as the significance of the possible associations for the oncology practice. Indeed, according to my knowledge and by reviewing the available relevant literature, such researches have not been found. Our study showed an identical overall epithelial without a statistically significant difference in stromal Sdc1 expression in two of the most common types of breast cancer - ductal and lobular, proved the role of Sdc1 in the progression of both histological types and in the development of metastatic potential of ductal cancer, but also determined that strong Sdc1 expression in regional IDC metastases is a highly potent source of further tumor progression (38).

\section{CONCLUSION}

The control of the cell adhesion is partly mediated by the Sdc1, and understanding the underlying molecular mechanisms - besides the physiological phenomena of growth and development - is necessary in the pathological processes such as the tumor cell invasion and metastasizing. There are numerous studies on the Sdc1 in the malignomas of different origins and different body sites, very often with different, even controversial results. Its role and meaning in a breast cancer has been frequently investigated from the genetic-molecular and clinical-prognostic aspects, but there are still many unexplored niches in the context of its interactions with the microenvironment and many other molecular allies or opportunists. New research on histologically different types of breast cancer will more precisely define the function and significance of Sdc1 in their initial carcinogenesis, progression and metastasizing, as well as illuminate and link Sdc1 interactions with other known or possible new participants of the extremely demanding oncological pathology.

\section{Conflict of interest}

The author declares no conflict of interest regarding this paper

\section{Acknowledgement}

All photos shown in the article are author's

\section{REFERENCES}

1. Couchman JR, Woods A. Syndecans, signaling, and cell adhesion. J Cell Biochem. 1996;61(4):578-84.

2. Bernfield M, Götte M, Park PW, Reizes O, Fitzgerald ML, Lincecum J, Zako M. Functions of cell surface heparan sulfate proteoglycans. Annu Rev Biochem. 1999;68(1): 729-77.

3. Inki P, Jalkanen M. The role of syndecan-1 in malignancies. Ann Med. 1996;28(1):63-7.

4. Palaiologou M, Delladetsima I, Tiniakos D. CD138 (syndecan-1) expression in health and disease. Histol Histopathol. 2014;29(2):177-89.

5. Akl MR, Nagpal P, Ayoub NM, Prabhu SA, Gliksman M, Tai B, et al. Molecular and clinical profiles of syndecan-1 in solid and hematological cancer for prognosis and precision medicine. Oncotarget. 2015;6(30): 28693-715.

6. Szatmári T, Ötvös R, Hjerpe A, Dobra K. Syndecan-1 in cancer: implications for cell signaling, differentiation, and prognostication. Dis Markers. 2015;2015; 796052

7. Khotskaya YB, Dai Y, Ritchie JP, MacLeod V, Yang Y, Zinn K, Sanderson RD. Syndecan-1 is required for robust growth, vascularization, and metastasis of myeloma tumors in vivo. J Biol Chem. 2009;284(38): 26085-95.

8. Sanderson RD, Hinkes MT, Bernfield M. Syndecan-1, a cell-surface proteoglycan, changes in size and abundance when keratinocytes stratify. J Invest Dermatol. 1992;99(4): 390-6.

9. Inki P, Larjava H, Haapasalmi K, Miettinen HM, Grenman R, Jalkanen M. Expression of syndecan- 1 is induced by differentiation and suppressed by malignant transformation of human keratinocytes. Eur J Cell Biol. 1994;63(1):43-51.

10. Vainio S, Jalkanen M, Bernfield M, Saxén L. Transient expression of syndecan in mesenchymal cell aggregates of the embryonic kidney. Dev Biol. 1992;152 (2):221-32.

11. Takeichi M. Cadherin cell adhesion receptors as a morphogenetic regulator. Science. 1991;251(5000):1451-5.

12. Elenius K, Vainio S, Laato M, Salmivirta M, Thesleff I, Jalkanen M. Induced expression of syndecan in healing wounds. J Cell Biol. 1991;114(3):585-95.

13. Saleh ME, Gadalla R, Hassan H, Afifi A, Götte M, ElShinawi M, et al. The immunomodulatory role of tumor Syndecan-1 (CD138) on ex vivo tumor microenvironmental $\mathrm{CD} 4+\mathrm{T}$ cell polarization in inflammatory and non-inflammatory breast cancer patients. PLoS One. 2019;14(5):e0217550.

14. Lim G-H, Tan P-H, Jara-Lazaro AR, Thike AA, Sim W-C, Yap V-B, Yip G W-C. Syndecan-1 is a potential 
biomarker for triple-positive breast carcinomas in Asian women with correlation to survival. Singapore Med J. 2014;55(9):468-72.

15. Hallberg G, Andersson E, Naessén T, Ordeberg GE. The expression of syndecan- 1 , syndecan- 4 and decorin in healthy human breast tissue during the menstrual cycle. Reprod Biol Endocrinol. 2010;8:35.

16. Haslam SZ, Woodward TL. Host microenvironment in breast cancer development: epithelial - cell - stromal - cell interactions and steroid hormone action in normal and cancerous mammary gland. Breast Cancer Res. 2003;5:208-15.

17. Lofgren L, Sahlin L, Jiang S, Von Schoultz B, Fernstad R, Skoog L, Von Schoultz E. Expression of syndecan-1 in paired samples of normal and malignant breast tissue from postmenopausal women. Anticancer Res. 2007;27(5A):3045-50.

18. Lundström E, Sahlin L, Skoog L, Hägerström T, Svane G, Azavedo E, et al. Expression of Syndecan-1 in histologically normal breast tissue from postmenopausal women with breast cancer according to mammographic density. Climacteric. 2006;9(4):277-82.

19. Fahlén $M$, Zhang $H$, Löfgren L, Masironi B, von Schoultz E, von Schoultz B, Sahlin L. Expression of cyclooxygenase-1 and cyclooxygenase-2, syndecan-1 and connective tissue growth factor in benign and malignant breast tissue from premenopausal women. Gynecol Endocrinol. 2017;33(5):353-8.

20. Stanley MJ, Stanley MW, Sanderson RD, Zera R. Syndecan-1 expression is induced in the stroma of infiltrating breast carcinoma. Am J Clin Pathol. 1999; 112(3):377-83.

21. Maeda T, Desouky J, Friedl A. Syndecan-1 expression by stromal fibroblasts promotes breast carcinoma growth in vivo and stimulates tumor angiogenesis. Oncogene. 2006;25(9):1408-12.

22. Maeda T, Alexander CM, Friedl A. Induction of syndecan-1 expression in stromal fibroblasts promotes proliferation of human breast cancer cells. Cancer Res. 2004;64(2):612-21.

23. Mennerich D, Vogel A, Klaman I, Dahl E, Lichtner RB, Rosenthal A, et al. Shift of syndecan-1 expression from epithelial to stromal cells during progression of solid tumours. Eur J Cancer. 2004;40(9):1373-82.

24. Burbach BJ, Friedl A, Mundhenke C, Rapraeger AC. Syndecan-1 accumulates in lysosomes of poorly differentiated breast carcinoma cells. Matrix Biol. 2003; 22(2):163-77.

25. Burbach BJ, Ji Y, Rapraeger AC. Syndecan-1 ectodomain regulates matrix-dependent signaling in human breast carcinoma cells. Exp Cell Res. 2004;300(1): 234-47.

26. Kainulainen V, Wang H, Schick C, Bernfield M. Syndecans, heparan sulfate proteoglycans, maintain the proteolytic balance of acute wound fluids. J Biol Chem. 1998;273(19):11563-9.

27. Sayyad MR, Puchalapalli M, Vergara NG, Wangensteen SM, Moore M, Mu L, et al. Syndecan-1 facilitates breast cancer metastasis to the brain. Breast Cancer Res Treat. 2019;178(1):35-49.

28. Yang Y, Macleod V, Miao H-Q, Theus A, Zhan F, Shaughnessy JD Jr, et al. Heparanase enhances syndecan-1 shedding: a novel mechanism for stimulation of tumor growth and metastasis. J Biol Chem. 2007;282(18):13326-33.

29. Nikolova V, Koo CY, Ibrahim SA, Wang Z, Spillmann $D$, Dreier $R$, et al. Differential roles for membranebound and soluble syndecan-1 (CD138) in breast cancer progression. Carcinogenesis. 2009;30(3):397-407.

30. Eshchenko TY, Rykova VI, Chernakov AE, Sidorov SV, Grigorieva EV. Expression of different proteoglycans in human breast tumors. Biochemistry (Mosc). 2007;72:1016-20.

31. Tsanou E, Ioachim E, Briasoulis E, Charchanti A, Damala K, Karavasilis V, et al. Clinicopathological study of the expression of syndecan- 1 in invasive breast carcinomas. Correlation with extracellular matrix components. J Exp Clin Cancer Res. 2004;23(4):641-50.

32. Yang N, Friedl A. Syndecan-1-induced ECM fiber alignment requires integrin $\alpha v \beta 3$ and syndecan-1 ectodomain and heparan sulphate chains. PLoS One. 2016;11(2):e0150132.

33. Guarino M, Rubino B, Ballabio G. The role of epithelial-mesenchymal transition in cancer pathology. Pathology. 2007;39(3):305-18.

34. Larue L, Bellacosa A. Epithelial-mesenchymal transition in development and cancer: role of phosphatidylinositol 3' kinase/AKT pathways. Oncogene. 2005; 24(50):7443-54.

35. Thanakit V, Ruangvejvorachai P, Sampatanukul P. Expression of E-cadherin and syndecan-1 in axillary lymph node metastases of breast cancer with and without extracapsular extension. J Med Assoc Thai. 2008;91(7):1087-92.

36. Kato M, Saunders S, Nguyen H, Bernfield M. Loss of cell surface syndecan-1 causes epithelia to transform into anchorage-independent mesenchyme-like cells. Mol Biol Cell. 1995;6(5):559-76.

37. Leppä S, Vleminckx K, Van Roy F, Jalkanen M. Syndecan-1 expression in mammary epithelial tumor cells is E-cadherin-dependent. J Cell Sci. 1996;109(Pt6): 1393-403.

38. Miše I, Vučić M . Comparison of syndecan-1 immunohistochemical expression in lobular and ductal breast carcinoma with nodal metastases. Anal Cell Pathol (Amst). 2018;2018:9432375.

39. Ellis IO, Schnitt SJ, Sastre-Garau X, Bussolati G, Tavassoli FA, Eusebi V, et al. Invasive breast carcinoma. In: Tavassoli FA, Devilee P, editors. Tumours of the breast and female genital organs. World health organization classification on tumours. Lyon: IARC Press; 2003. p. 13-60.

40. Tiemann K, Weigel MT, Alkatout I, Wenners AS, Mundhenke H, Schäfer FW, et al. Significance of syndecan-1 expression in ductal carcinoma in situ of the breast. Anticancer Res. 2014;34(7):3607-16. 
41. Götte M, Kersting C, Radke I, Kiesel L, Wülfing P. An expression signature of syndecan-1 (CD138), E-cadherin and c-met is associated with factors of angiogenesis and lymphangiogenesis in ductal breast carcinoma in situ. Breast Cancer Res. 2007;9(1):R8.

42. Baba F, Swartz K, van Buren R, Eickhoff J, Zhang Y, Wolberg W, Friedl A. Syndecan-1 and syndecan-4 are overexpressed in an estrogen receptor-negative, highly proliferative breast carcinoma subtype. Breast Cancer Res Treat. 2006;98(1):91-8.

43. Leivonen M, Lundin J, Nordling S, von Boguslawski K, Haglund C. Prognostic value of syndecan-1 expression in breast cancer. Oncology. 2004;67(1):11-8.

44. Barbareschi M, Maisonneuve P, Aldovini D, Cangi MG, Pecciarini L, Angelo Mauri F, et al. High syndecan-1 expression in breast carcinoma is related to an aggressive phenotype and to poorer prognosis. Cancer. 2003;98(3):474-83.

45. Loussouarn D, Campion L, Sagan C, Frenel J-S, Dravet F, Classe J-M, et al. Prognostic impact of syndecan-1 expression in invasive ductal breast carcinomas. Br J Cancer. 2008;98(12):1993-8.

46. Malek-Hosseini Z, Jelodar S, Talei A, Ghaderi A, Doroudchi M. Elevated syndecan-1 levels in the sera of patients with breast cancer correlate with tumor size. Breast Cancer. 2017;24(6):742-7.
47. Götte M, Kersting C, Ruggiero M, Tio J, Tulusan AH Kiesel L, Wülfing P. Predictive value of syndecan-1 expression for the response to neoadjuvant chemotherapy of primary breast cancer. Anticancer Res. 2006;26 (1B):621-7.

48. Tokes AM, Szasz AM, Farkas A, Toth AL, Dank M, Harsanyi L, et al. Stromal matrix protein expression following preoperative systemic therapy in breast cancer. Clin Cancer Res. 2009;15(2):731-9.

49. Kind S, Jaretzke A, Büscheck F, Möller K, Dum D, Höflmayer D, et al. A shift from membranous and stromal syndecan-1 (CD138) expression to cytoplasmic CD138 expression is associated with poor prognosis in breast cancer. Mol Carcinog. 2019;58(12):2306-15.

50. Soliman NA, Yussif SM, Shebl AM. Syndecan-1 could be added to hormonal receptors and HER2/neu in routine assessment of invasive breast carcinoma, relation of its expression to prognosis and clinicopathological parameters. Pathol Res Pract. 2019;215(5):977-82.

51. Qiao W, Liu H, Guo W, Li P, Deng M. Prognostic and clinical significance of syndecan-1 expression in breast cancer: A systematic review and meta-analysis. Eur J Surg Oncol. 2019;45(7):1132-7.

Sažetak

\section{VRIJEDNOST IMUNOHISTOKEMIJSKOG ODREĐIVANJA SYNDECANA-1 U KARCINOMU DOJKE}

\section{Miše}

Syndecan-1 (Sdc1) je transmembranski heparan-sufatni proteoglikan, receptor za ekstracelularni matriks, organizator adhezije stanica-matriks, uključen u adheziju na svim kontaktnim staničnim površinama. Integrira različite stanične signale i signale među čimbenicima rasta te modulira staničnu proliferaciju, kancerogenezu, migraciju i angiogenezu. Stanično kretanje i invazija prvo zahtjevaju gubitak Sdc1. Ekspresija Sdc1 se gubi neposredno prije nego stanica promijeni oblik ili lokaciju, što smanjuje adhezivnost a povećava staničnu mobilnost i invazivni potencijal. Otpuštanjem Sdc1 s površine stanica (shedding) omogućava se rast tumora i metastaziranje. Takva promjena ekspresije Sdc1 od presudne je važnosti u tranziciji invazivnih karcinoma dojke u metastatski fenotip i prati epitelno-mezenhimalnu tranziciju (EMT). Molekule uključene u EMT-u potencijalni su ciljevi za farmakoterapiju i kontrolu tumorskog metastaziranja. Moguće da je proteolitička konverzija netopivog (koreceptor vezan za membranu) u topivi oblik Sdc1, okidač skretanju proliferativne faze raka dojke u invazivnu, što također može biti od dijagnostičko-terapijske koristi. Stromalna ekspresija Sdc1 znači ne samo jednostavnu fiksaciju Sdc1 otpuštenog s epitelnih stanica na stromalne, nego i autohtonu sintezu Sdc1 u reaktivnim stromalnim fibroblastima. Interakcijom s heparin-vezujućim čimbenicima rasta, Sdc1 se kumulira u stromi invazivnih tumora čime doprinosi njenoj proliferaciji i neoangiogenezi. U više od 70\% karcinoma dojke Sdc1 je induciran u stromalnim fibroblastima, uz značajnu razliku ekspresije Sdc1 između strome malignog i nemalignog tkiva dojke. Iako dio karcinoma dojke gubi Sdc1, kod većine je izražen ili prekomjerno izražen, a njegova ekspresija se veže uz slabiji odgovor tog karcinoma na kemoterapiju. Studije o prognostičkom značenju Sdc1 u karcinomu dojke pokazale su nejednake rezultate, što upućuje na potrebu za novim istraživanjima na ovu temu.

KLJUČNE RIJEČI: dojka, karcinom, syndecan-1, imunohistokemija, izraženost 